Nataliia Orlova, Dr. Sc. (Public Administration), Professor, Kyiv National University of Trade and Economics, Department of Public Management and Administration (Kyiv, Ukraine)

Anna Chechel, Doctor of Economics Sciences, Associate Professor, Donetsk State University of Management, Department of Public Administration and Management (Mariupol, Ukraine)

\title{
THE DETERMINANTS OF UKRAINE'S SUSTAINABLE DEVELOPMENT
}

Abstract. The aim of the article was to develop scientific and practical recommendations for improving the sustainable development mechanisms at the central, regional, local levels and levels of enterprises in the social and economic spheres of Ukraine for the effective management decisions adoption and implementation. The problems and peculiarities of the responsible state in the conditions of sustainable development are defined. The basic directions of development of socially responsible education and science and their influence on the labor market and professional employment of youth are defined. Scientific and practical recommendations on the formation of effective mechanisms of sustainable development at the state, regional and local level are offered.

Keywords: corporate social responsibility, sustainable development, the determinants of sustainable development, criteria for determining environmental corporate responsibility

Introduction. During quite a long period of time Ukraine has been seeking ways to overcome the crisis phenomena in a lot of social and economic life spheres. On the one hand, a certain disparity of global development is common to all countries of the world; on the other hand, the approaches to this issue are different for each country. The basic alternative model of social progress in Ukraine and the world is the concept of sustainable development. The domestic and world scientific communities do not cease to look for ways of the most adequate and scientifically grounded development and evaluation of sustainable development processes.

It is essential to study scientific and methodological approaches in shaping the strategic directions of European countries development, which is relevant for Ukraine in the conditions of European integration processes, the implementation of the sustainable development strategy and the civil democratic society construction. The Ukraine's 
transformation to sustainable economic development, its integration into the European and world community requires the modern practices introduction of interaction between the state and business, as well as business and society, which would allow strengthening the mutual responsibility of all participants in public life, create conditions for the further stable society development.

The main task of public administration in the country social and economic sphere is to provide appropriate conditions for sustainable economic development and, on that basis, to create guidelines for an effective social policy that addresses the main tasks of ensuring sustainable balanced economic growth, high level of employment and productivity, effective use of human resources in the state, the development of small business, the implementation of the social responsibility principles and the formation of an effective regional system in Ukraine.

In the modern world, socially responsible business activity is a recognized tradition, which is followed by a number of large, medium and even small enterprises. Given the extraordinary social and economic significance of corporate social responsibility (CSR), its development is a matter of particular concern to public authorities in many world countries and leading international organizations. The manifestation of this is the development of CSR standards and measures to stimulate business to such responsibility. In most European Union countries (EU), state programs of support and stimulation of CSR have been developed and implemented, in which the state connects private and public sector companies to jointly fulfill socially important tasks, stimulates business to socially responsible activities.

The purpose of the research is to develop scientific and practical recommendations for improving the sustainable development mechanisms at the central, regional, local levels and levels of enterprises in the social and economic spheres of Ukraine for the effective management decisions adoption and implementation.

In order to realize this purpose, the following tasks have been set: to identify issues and peculiarities of a responsible state in conditions of sustainable development; to determine the main directions of socially responsible education and science development and their influence on the labour market and youth professional employment; to develop scientific and practical recommendations on the formation of effective mechanisms of sustainable development at the state, regional and local levels. Solving the tasks of the project will allow substantiating the scientific and practical results on the sustainable development mechanisms implementation at different levels of governance in the social and economic sphere, based on 
the conceptual foundations formation of social responsibility, which solves important issues of the state social and economic policy in Ukraine.

Methodological basis of the research. The methodological basis of the research is the logical-dialectical method of perceiving the sustainable development mechanisms implementation in modern European and national economies.

The scientific methods used to analyse and synthesize International Sustainable Competitiveness Country Index (GSCI), World Bank data, Eurostat, Ranking of RobecoSAM countries, monitoring of the global indicators for achieving sustainable development goals based on 96 indicators on information from the state statistics of Ukraine, 52 of which are in full compliance with existing international standards [3-9].

For the assessment of corporate social responsibility, the triple-bottom-line method, the balanced estimation map, and the methodology of the London Group for Comparative Analysis, the SA 8000 standard, the European Quality Model, the Corporate Charity Index, the Social Index, the Dow Jones Index, the FTSE4Good Index, and the DominiSocial Index are applied [7-9, 17].

The research information base is the scientific works of domestic and foreign scientists, laws of Ukraine, decrees of the President of Ukraine, resolutions of the Cabinet of Ministers of Ukraine, normative acts and statistical materials of the State Statistics Committee of Ukraine and the Ministry of Social Policy, legislation of the countries of Central and Eastern Europe, statistical materials and economic studies of international rating agencies, financial reports of corporations, materials of author's own research.

Main part. Line of the research. The process of forming national strategies in the new realities of Ukraine coincided in time with the sustainable development goals adoption (SDG) and their priority in the national reform agenda determination. The Ministry of Economic Development and Trade, on behalf of the Government of Ukraine in partnership with the United Nations (UN), began the process of nationwide local consultations on the SDG, which lasted until 2016 in Kyiv and ten regions of Ukraine. About 1,000 representatives of government (national and local), academia, and civil society and UN agencies were involved in the consultation. At present, Ukraine is undergoing reforms that must be in line with the declared strategic goals of sustainable development proclaimed at the global level, which involves finding a balance between economic, environmental and social components of development as well as securing peace and social harmony [18].

1. In the context of reforming public administration and local self-government in Ukraine, the main development vector in the Strategy of Sustainable Development 
implementation is ensuring sustainable development of the state, carrying out structural reforms and, consequently, raising living standards [9].

The priority directions of the state regional policy on the main components of sustainable development can be defined as the following: stimulation and support of local initiatives on effective use of internal potential of regions for healthy living environment creation and maintenance, people's quality of life improvement; territorial differentiation reduction by the index of regional human development, first of all between the capital city of Kiev and other regions of Ukraine; formation of regions' competitiveness through the development and implementation of programs and projects in order to enhance the territories competitiveness; stimulation of interregional integration, overcoming interregional alienation, integration of regional economic, informational and educational sectors into a single all-Ukrainian one; creation of an effective system of environmental protection by taking into account the environmental component in regional development strategies, improving the material, financial, information, personnel and other resource support for the regions development, facilitating the tasks implementation by local self-government bodies.

2. Along with economic factors, increasingly important role in ensuring competitiveness, achieving high productivity and profitability of production is allocated by non-economic indicators of the company's activity, i.e. the level of employees' social security, the development and implementation of support programs for boarding schools, hospitals and schools, the introduction of a quality control mechanism at the enterprise, implementation of environmentally friendly and energy saving technologies, etc.

The idea of the concerned party concept is that each organization, business entity, government body, or public association have circles of interested parties that influence their activities or are affected by this activity at present moment and in the future. Social responsibility of enterprises in the market environment is realized through various directions of interaction with the parties concerned: social responsibility to employees, social responsibility to the state, social responsibility to the region community, territories in which the enterprise operates (Table 1). 
Table 1

The most popular methods of assessing social responsibility (foreign experience)

\begin{tabular}{|c|c|}
\hline Evaluation Methods & The most prominent researchers \\
\hline The use of self-assessment systems (questionnaires) & $\begin{array}{l}\text { [Aupperle, Carroll, Hatfield, 1985; } \\
\text { Aupperle, Van Pham, 1989] }\end{array}$ \\
\hline Content analysis of open sources of CSR information & [Abbott, Monsen, 1979] \\
\hline Using Reputation Indices and Ratings & $\begin{array}{l}\text { [Gizatullin, 2007; Cochran, Wood, } \\
\text { 1984; Aupperle, Carroll, Hatfield, } \\
\text { 1985; Wokutch, Spencer, 1987; } \\
\text { McGuire, Sundgren, Schneeweis, } \\
\text { 1988; Herremans, Akathaporn, } \\
\text { McInnes, 1993; Brown, Perry, 1994; } \\
\text { 1995; Simerly, 1994; Griffin, Mahon, } \\
\text { 1997; Preston, O’Bannon, 1997; } \\
\text { Waddock, Graves, 1997; Stanwick, } \\
\text { Stanwick, 1998; Heinze, Sibary, } \\
\text { Sikula, 1999] }\end{array}$ \\
\hline Social audit and external observers' evaluation & [Vance, 1975; Sonnenfeld, 1982] \\
\hline $\begin{array}{l}\text { The values and principles assessment of corporate } \\
\text { CSR }\end{array}$ & [Davenport, 2000] \\
\hline
\end{tabular}

The balance of equilibrium in the state, its integrity and sustainable development can be ensured only if the whole set of economic, environmental and socio-institutional conditions and interests of the country are taken into account, the effectiveness and efficiency of socio-economic policy and mechanisms for its practical implementation. Developing specific CSR trends in each country based on the goals and objectives of the country's strategic development, it influences the integration and globalization processes in the international space, improves the transparency of the corporation in the financial market, enhances the competitiveness of corporations, implementing and forming corporate social standards [3].

In recent years, the process of CSR policy implementation by Ukrainian companies has gained positive momentum. In Ukraine, most companies, despite their size, do not have a defined social responsibility strategy, are in compliance with legislation and charitable projects. Ukrainian business leaders are active in charitable activities (strategic philanthropy) and use public relations tools. Almost all major companies carry out business process improvement projects with some social or environmental benefits, but most do not link such business projects to their own social responsibility. Every year, the number of companies and their social projects is growing. 
In 2016, a new CSR course for company strategies was selected - a focus on the UN Sustainable Development Goal. CSR Development Center first introduced Ukrainian companies' practices within the Global Goals. Most of the cases were devoted to Objective 3 on health and Goal 4 on quality education.

Under Objective 3 of the United Nations Sustainable Development, Lenovo Ukraine has launched a social project "Do Good," which aims to provide medicines and distance learning for children with cancer in Ukraine. As a result of the project, funds were raised for an annual supply of accompanying medicines for children with cancer. The essence of the project was that for every purchase of Lenovo equipment (laptop, computer, tablet) in stores all over Ukraine, $50 \mathrm{UAH}$. transferred to a charitable foundation. However, prices did not increase. The project involved all retailers and online stores selling Lenovo appliances [3].

Another major project aimed at ensuring a healthy lifestyle is the project "I want to hear the world around", implemented by the Ukrainian telecommunications operator LIFECELL. This project is aimed at supporting people with hearing and hearing impairment at the SUAVAG Medical Center for Hearing and Speech in Kyiv [3].

Due to the events of 2014 - annexation of Crimea, and later the armed conflict in eastern Ukraine, Nova Poshta launched the social project "Humanitarian Mail of Ukraine". The project provided an opportunity for volunteer organizations and initiative groups to send and receive humanitarian supplies free of charge at any company outlet throughout Ukraine. Almost 300 accredited volunteer organizations have been able to ship humanitarian supplies free of charge. As a result, for the period 2014-2015, 55335 parcels were delivered, the weight of these cargoes is $9767 \mathrm{t}[10]$.

The CSR analysis conducted by the CSR Development Center in 2017 made it possible to identify the leading CSR companies in the domestic market: Deloitte, Monsanto, Pharmak, Watsons Ukraine, Eleks, Energoatom, Syngenta, $1+1$ media, Loreal Ukraine LLC », Kredobank, MHP, Nova Poshta, CRH, DEC, Nestle and others [21].

An important characteristic of Ukrainian companies is their closedness to the general public. Research shows that reporting on social responsibility practices is predominantly large corporations and companies. Small and medium-sized businesses remain largely left out of this process. The main reasons hampering the development of social responsibility in small and medium-sized businesses are lack of funds, lack of regulation and lack of encouragement by the state for responsible activities, unfavorable political situation, high tax rates and complex administration of taxes, frequent changes in economic legislation, pressure 
and corruption. The main reason is the low level of awareness among buyers about the practices used by companies.

In addition, there is a set of general economic factors and risks that influence the decision on socially responsible behavior of the enterprise. Social responsibility reduces the chances of an enterprise to achieve financial success, limits the possibility of obtaining more profit, thereby leading to the violation of the achievement of the main purpose of commercial activity - the principle of profit maximization [21].

Thus, the main problems hindering the development of CSR in Ukraine are: financial and economic and political crisis (negative price environment, low demand for Ukrainian products in international markets, high inflation),

3. The directions of education social responsibility realization, which are based on supplying the society with professionals of a certain level, helping to extend social barriers in society, dissemination on social responsibility knowledge in society, scientific and industrial cooperation with business, regardless of any factors, ought to be implemented in a developed country. The high level of youth unemployment is due to the fact that a significant part of young people do not have the appropriate professional skills and work experience. In addition, in Ukraine, the tendency of supply and demand inconsistency on the labor market is intensifying.

Institutions of higher education, through their main functions (research, training and public services) carried out in the context of institutional autonomy and academic freedom, have to increase their interdisciplinary orientation and promote critical thinking and active civic stance. It would contribute to sustainable development, social responsibility of citizens, welfare and the human rights realization, democracy values.

4. Nowadays, most global corporations pay close attention to the concepts of sustainable development and corporate social responsibility. In this context, large companies, which occupy leading positions in the fields of operation, are moving to a qualitatively new approach in corporate governance focused on its results in the field of sustainable development. Regular reporting on the corporation's activities effectiveness in terms of sustainable development promotes its market attractiveness, allows it to create a positive business image and business reputation for the state and society, enhance transparency and investment attractiveness (Table 2). 
Table 2

International organizations that develop international standards for reporting on sustainable development

\begin{tabular}{|c|c|}
\hline Organisation & The content of organisation activities \\
\hline 1 & 2 \\
\hline $\begin{array}{c}\text { International } \\
\text { Organization for } \\
\text { Standardization, ISO }\end{array}$ & $\begin{array}{l}\text { One of the largest organisations involved in the development of } \\
\text { international standards covering almost all aspects of technology } \\
\text { and business, including the field of social reporting (ISO 26000) }\end{array}$ \\
\hline $\begin{array}{l}\text { United Nations } \\
\text { Environment Programme } \\
\text { Finance Initiative, UNEP } \\
\text { FI }\end{array}$ & $\begin{array}{l}\text { The initiative employs more than } 200 \text { members in three financial } \\
\text { sectors: banking, insurance and investment, which recognize } \\
\text { sustainable development as part of collective responsibility for its } \\
\text { environmental performance and society results }\end{array}$ \\
\hline Accountability & $\begin{array}{l}\text { It helps corporations, non-profit organizations and governments } \\
\text { make ethical, environmental, social and managerial accountability } \\
\text { to their organizational structures. }\end{array}$ \\
\hline $\begin{array}{l}\text { Global Reporting } \\
\text { Initiative, GRI }\end{array}$ & $\begin{array}{l}\text { It promotes the use of Sustainability Reporting as a means of } \\
\text { maintaining sustainability of the organization and contributing to } \\
\text { the global economy sustainability }\end{array}$ \\
\hline $\begin{array}{l}\text { Carbon Disclosure } \\
\text { (Carbon Disclosure } \\
\text { Project, CDP) }\end{array}$ & $\begin{array}{l}\text { It offers an online questionnaire for companies looking for a way } \\
\text { to draw a report on their impact on the environment }\end{array}$ \\
\hline $\begin{array}{l}\text { The International } \\
\text { Integrated Reporting } \\
\text { Council, IIRC }\end{array}$ & $\begin{array}{l}\text { The International Council for Integrated Reporting is a global } \\
\text { coalition of regulators, investors, companies, non-governmental } \\
\text { organizations, which develops standards for integrated reporting } \\
\text { that allows companies to evaluate their financial, social and } \\
\text { performance indicators in the environmental and management } \\
\text { sectors in a comprehensive manner }\end{array}$ \\
\hline $\begin{array}{l}\text { Sustainability } \\
\text { Accounting Standards } \\
\text { Board, SASB }\end{array}$ & $\begin{array}{l}\text { It is a non-profit organization that has divided companies into ten } \\
\text { sectors covering } 89 \text { industries by degree of their resources and } \\
\text { potential and developed sustainable accounting and reporting } \\
\text { standards for them in order to disclose information about their } \\
\text { environmental, social and managerial impact on the environment. }\end{array}$ \\
\hline
\end{tabular}

The introduction of social reporting in Ukraine is primarily interested in companies that have entered or are entering the world markets. One of the key issues that prompt domestic companies to compile non-financial reports is the impact of globalization processes, the desire to enter the world markets, the need for a sustainable reputation of the company in the society.

According to KPMG, an international auditing company, the number of companies interested and actively using CSR strategies is steadily increasing and as of 1 January 2017 is $75 \%$ of the total number of companies in the world. Over the past two years, the number of 
such companies in America has increased by 6\%, overtaking the Asia-Pacific region. Several countries with the highest CSR ratings in the world, such as Japan, India, Malaysia and Taiwan, are located in the Asia-Pacific region (Table 3).

Table 3

Dynamics of CSR management by companies in the regions of the world in 2011-2017, $\%$ [19]

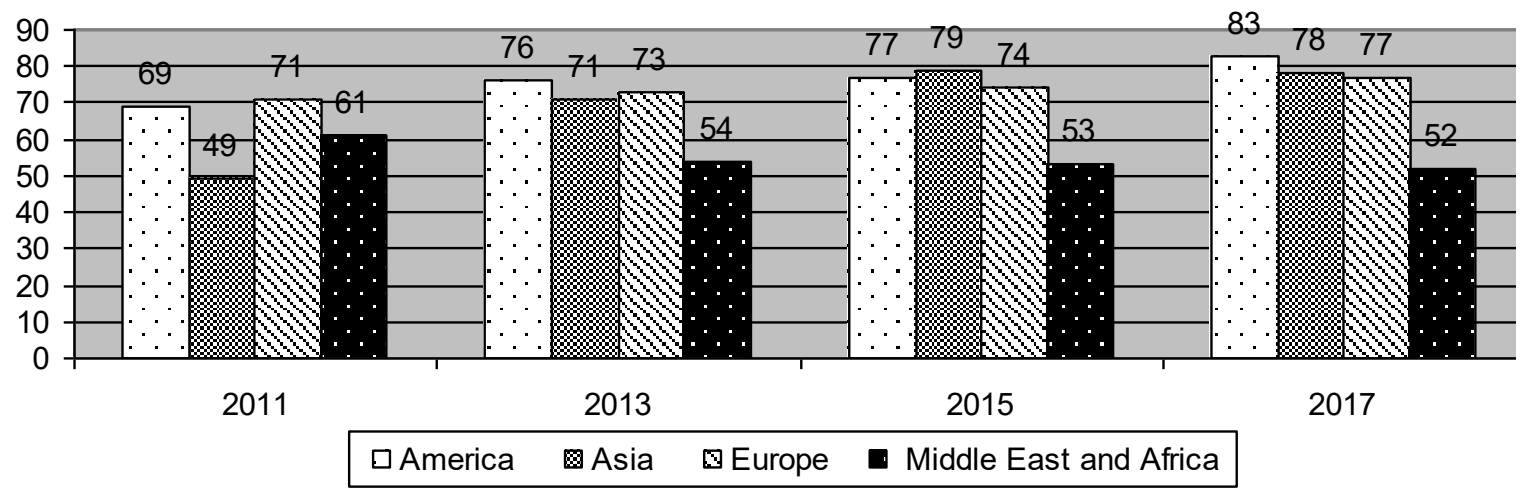

A study of the business practices of 170,000 companies in 15 countries around the world, conducted by the American Reputation Institute and a Boston-based reputation management consulting firm, identified leaders as consumers who are perceived as the strongest and most socially responsible companies.

The overall rating is based on the following indicators: company reputation, management strategy, consumer relations, positive impact on society and attitude towards employees. Lego is among the leaders in the list of leading CSR companies with 74.4 points (Table 4). The company has risen from the fifth position in the ranking last year due to ethical behavior, transparency, honest business conduct, active participation in environmental programs.

Table 4

Top 10 Corporate Social Responsibility Companies in 2017 [20]

\begin{tabular}{|c|c|c|}
\hline Rating & Company & CSR Summary \\
\hline 1 & LEGO Group & 74,4 \\
\hline 2 & Microsoft & 74,1 \\
\hline 3 & Google & 73,9 \\
\hline 4 & The Walt Disney Company & 73,5 \\
\hline 5 & BMW Group & 71,5 \\
\hline 6 & Intel & 71,1 \\
\hline 7 & Robert Bosch & 71 \\
\hline 8 & Cisco Systems & 71 \\
\hline 9 & Rolls-Royct Aerospace & 70,7 \\
\hline 10 & Colgate-Palmolive & 70,4 \\
\hline
\end{tabular}


The assessment of the activities of many international corporations concludes that social responsibility contributes to the development of companies and, conversely, the avoidance of social responsibility reduces the chances of success of the company.

5. Corporate social responsibility is also an integral part of environmental protection, the rational use of natural resources, the creation of appropriate environmental conditions for businesses and human life. It is the environmental safety of the enterprise that is an indicator of its corporate social responsibility. The main elements of environmental corporate responsibility [23]:

1. Implementation of corporate environmental policy, which envisages compliance with environmental legislation, open environmental policy, a system of environmental principles and standards.

2. Environmental audit, which helps to determine the priority areas of the environmental policy of the organization; provides an assessment of the environmental impact of the organization's activities.

3. Involvement of employees in environmental initiatives, organizations raise environmental responsibility of employees through aspects of environmental ethics (environmental policy of an organization can only be fully implemented if management, employees and their families are involved in solving environmental problems).

4. Environmental friendliness of suppliers, which involves the use of environmentally friendly raw materials and materials made using environmental technologies.

5. Production of environmentally friendly goods through the use of environmentally friendly materials for their production, the use of innovative waste processing technologies, the use of closed cycle technologies, etc.

According to a survey conducted in Germany, the main motives of the enterprise for environmental protection are [24]: 1) environmental / social responsibility $(30.5 \%) ; 2$ ) legislation / state regulation $(22.5 \%) ; 3)$ firm viability guarantees / risk prevention $(12.1 \%)$; 4) image $(9.2 \%) ; 5)$ others. From the survey we can conclude that the role of state regulation in the environmental issue is one of the main. To study the environmental situation in Ukraine, we generally use the country's rating on the Environmental Sustainability Index developed by the Center for Environmental Law and Policy at Yale University (USA). At the beginning of 2017, Ukraine ranked 44th in the ranking, improving its results by $25 \%$ in 10 years, and ended up between Argentina (43) and Cuba (45) [22]. It should be noted that countries in the ranking 
are ranked on the basis of criteria grouped into 9 categories, an extensive analysis of which can identify the country's strengths and weaknesses in environmental performance. For example, out of 44 places, Ukraine ranks 130th out of 180 countries on the criterion of "biodiversity and habitat", which characterizes the country's efforts to address species conservation issues within its borders; 144 - in terms of air pollution, which affects human health and characterizes air quality [24]. The top 25 place is given to Ukraine by measuring the dynamics of carbon emissions per unit of GDP. Modern domestic realities testify to the improvement and a more responsible attitude to the environment in our country at all levels. In these circumstances, particular attention should be paid to the fact that the use of natural resources by both citizens and enterprises and organizations must be carried out in compliance with mandatory environmental requirements [25]:

- rational and economical use of natural resources on the basis of active introduction of innovative technologies;

- taking measures to prevent damage, pollution, depletion of natural resources, negative impact on the environment;

- application of biological, chemical methods for improving the quality of natural resources;

- carrying out economic activities without violating the environmental rights of others;

- conservation of the territories and objects of the nature reserve fund, which are subject to special protection.

So, today, humanity is determined to achieve sustainable socio-ecological-economic development. One approach to defining environmental corporate responsibility is to meet three criteria [20], such as compliance with environmental commitments, energy and raw materials management, and effective stakeholder engagement.

In our opinion, environmental responsibility of business as a component of corporate social responsibility can contribute to resolving emerging environmental problems and prevent potential conflicts in business, society and government relations, and ensure domestic producers' perception at the international level. At the same time, in order to achieve sustainable development of the country, the environmental responsibility of business should not be a solitary situation, but a vital philosophy for society, businesses and government. Strengthening individual and corporate environmental responsibility as components of social responsibility can make a significant contribution to solving environmental problems and 
preventing possible conflicts in business, society and government relations, and improving the perception of domestic producers internationally (Table 5).

At the same time, according to scientists, in order to achieve sustainable development of the country, environmental responsibility must become a vital philosophy for society, businesses and authorities [24]. It is about minimizing the environmental burden from the development and growth of actors in the real sector of the economy, where developing and implementing a system of levers of state regulation to accelerate the transition to "clean" technologies and environmentally safe areas of economic activity is seen as a crucial and most effective step to be taken in Ukraine .

Table 5

\section{Criteria for determining environmental corporate responsibility}

\begin{tabular}{|c|c|}
\hline Criteria & Features of environmental social responsibility \\
\hline $\begin{array}{l}\text { Compliance } \\
\text { with } \\
\text { environmental } \\
\text { commitments }\end{array}$ & $\begin{array}{l}\text { - the corporate vision of the company is fully consistent with the concept of } \\
\text { sustainable development and the concept of social responsibility; } \\
\text { - protection and restoration of the natural environment are determined by the } \\
\text { strategic priorities of the company; - Awareness that the economic system } \\
\text { operates within an ecosystem that is limited; } \\
\text { - the company complies with and acts in accordance with the requirements of } \\
\text { environmental legislation; } \\
\text { - the company is fully responsible for the environmental damage; } \\
\text { - promoting a corporate culture based on environmental values }\end{array}$ \\
\hline $\begin{array}{l}\text { Energy and } \\
\text { Raw } \\
\text { Materials } \\
\text { Management }\end{array}$ & $\begin{array}{l}\text { - efficient use of natural resources; } \\
\text { - creation and use of renewable energy and materials; } \\
\text { - the company is guided by system thinking in its activity; } \\
\text { - the company is trying to minimize its carbon footprint (if linked to its } \\
\text { business profile); } \\
\text { - ongoing analysis of environmental achievements and the search for new } \\
\text { environmental solutions; } \\
\text { - the company constantly analyzes the environmental costs and benefits }\end{array}$ \\
\hline $\begin{array}{l}\text { Effective } \\
\text { stakeholder } \\
\text { engagement }\end{array}$ & $\begin{array}{l}\text { - the company informs local communities and authorities about the } \\
\text { environmental impact of its activities; } \\
\text { - the company is accountable to the community and other stakeholders for its } \\
\text { current and future activities, as well as for past actions; - the company takes } \\
\text { into account the views and wishes of stakeholders when developing and } \\
\text { implementing its own projects; } \\
\text { - the company's activities are transparent, including information on the } \\
\text { environmental impact of its activities; } \\
\text { - the company constantly analyzes and regularly reports on the impact of its } \\
\text { activities on the environment }\end{array}$ \\
\hline
\end{tabular}


These levers, in our opinion, should be elaborated in the drafting of the Sustainable Development Strategy and the Innovative Model of Structural Adjustment of the Ukrainian Economy [23]. In addition, significant benefits from the introduction of environmental responsibility are gained by the state and society: addressing some of the key environmental issues, compliance with the norms and standards of the global economy, taking into account the environmental component, preserving the health of the population, etc.

Conclusions. By using adopted foreign experience it is possible to increase the level of effective functioning of the social security system and economic development in Ukraine by: developing the socially responsible state mechanisms; effective functioning and coordinated work of national, regional and local management systems in the economic and social spheres; democracy and transparency of social protection; clear scientific substantiation of measures on social protection and its normative and legal maintenance; further introduction of social responsibility mechanisms of various subjects of social development in terms of the European integration conditions.

\section{References}

1. Official site of the State Statistics Service of Ukraine [Electronic resource]. - 2016. - Access mode: http://www.ukrstat.gov.ua/

2. Official site of the Ministry of Social Policy [Electronic resource]. - 2016. - Access mode: http://www.msp.gov.ua/news/13732.html

3. Official website of the World Bank [Electronic resource]. - 2016. - Access mode: http://www.worldbank.org/

4. United Nations Development Assistance Framework Guidance, 2017, UNDG [Electronic resource] // - 2017. - Access mode: https://undg.org/document/2017-undafguidance/

5. Transforming our world: The 2030 Agenda for Sustainable Development, UN General Assembly Resolution, 21 October, 2015, A/RES/70/1. Par 4.

6. The Global Sustainable Competitiveness Index 2017 [Electronic resource] // - 2017. - Access mode: http://solability.com/the-global-sustainable-competitiveness-index/the-index

7. Country Sustainability Ranking [Electronic resource]. - 2017. - Access mode: http://www.robecosam.com/en/sustainability-insights/about-sustainability/countrysustainability-ranking/index.jsp

8. Eurostat [Electronic resource] // - 2017. - Access mode: http://ec.europa.eu/ eurostat/web/main 
9. Sustainable Development Strategy "Ukraine 2020" [Electronic resource] // Legislation / Verkhovna Rada of Ukraine. - Electronic text data. - Kyiv, 2015. - Access mode: http://zakon2.rada.gov.ua/laws/show/5/2015 (access date 22.12.2016). - Title from the screen.

10. Glac, K. (2010). The influence of shareholders on corporate social responsibility (Working Paper No 2.). Center for ethical business cultures: History of corporate responsibility project. Retrieved from http://www.cebcglobal.org/uploaded_files/ Glac_paper_on_Social_Investment_FINAL.pdf

11. Manescu, C. (2010). Economic implications of corporate social responsibility and responsible investments. University of Gothenburg: Department of economics School of business, economics and law University of Gothenburg. Retrieved from http://citeseerx.ist.psu.edu/viewdoc/download?doi=10.1.1.185.1306\&rep=rep1\&type=pdf

12. Cheng, B., Ioannou, I. and Serafeim, G. (2011). Corporate Social Responsibility and Access to Finance (Working Paper No 35 (1)). Strategic Management Journal. https://doi.org/10.2139/ssrn.1847085

13. Official site of World Data Center for Geoinformatics and Sustainable Development. Retrieved from http://wdc.org.ua/uk (in Ukr.).

14. UNDP in Ukraine (2017). Accelerating progress towards the Millennium Development Goals in Ukraine. Retrieved from http://www.ua.undp.org/content/ukraine/en/ home/sustainable-development-goals.html (in Ukr.).

15. Zghurovs'kyj, M. Z. Forsyth Ukraine's economy: term (2015-2020 years) and long term (2020-2030 years) time horizon. Kyiv: NTUU «KPI» (in Ukr.)

16. Corporate knights capital (2017). Key performance indicators. Retrieved from http://global100.org/key-performance-indicators/.

17. RobecoSAM AG (2017). Report about Industry group leaders in 2017. Retrieved from http://www.robecosam.com/en/sustainability-insights/about-sustainability/corporate$\underline{\text { sustainability-assessment/industry-group-leaders.jsp }}$

18. Orlova, N., Mokhova, J. (2018). The Ukraine`s competitiveness enhancement in conditions of sustainable economic development [Transformational processes the development of economic systems in conditions of globalization: scientific bases, mechanisms, prospects: collective monograph], Riga - Landmark, SIA.[in English] ISBN 978-9984-891$04-0$

19. Практики КСВ в Україні 2017 / Під ред. Саприкіної М.; Центр «Розвиток КСВ». - К.: 2018. -88 c. 
20. The KPMG Survey of Corporate Responsibility Reporting 2017 [Електронний pecypc] // KPMG. - Режим доступу: https://assets.kpmg.com/content/dam/kpmg/xx/pdf/ 2017/10/kpmg-survey-of-corporate-responsibility-reporting-2017.pdf

21. The Companies With The Best CSR Reputations In 2017 [Електронний ресурс// Forbes. - Режим доступу: https://www.forbes.com/sites/karstenstrauss/2018/02/08/thecompanies-with-the-best-csr-reputations-in-2017/\#319829623873

22. Гассий В.В. Экологическая ответственность бизнеса как элемент государственно-частного партнерства / В.В. Гассий, И.М. Потравный Маркетинг i менеджмент - 2011 - № 3. Т.1. - С. 179-187.

23. Грішнова О.А. Екологічний вектор соціальної відповідальності / О.А. Грішнова, В.П. Думанська // Економіка і управління. - 2011. - № 3. - С. 32-38.

24. Смоленніков Д.О. Роль екологічної відповідальності бізне- су на шляху сталого розвитку / Д.О. Смоленніков // Вісник Сумського державного університету. Серія «Економіка». - 2013. - № 4. - С. 35-39.

25. Крупина Н.Н. Власть и бизнес: экологическая проекция социальной ответственности / Н.Н. Крупина. - Пятигорск: Пятигорский гос. лингв. ун-т, - 2006.

26. Чечель А.О. Структурно-функціональна модель органу державного моніторингу соціально-екологічної відповідальності/ Чечель А.О./ Сучасні суспільні проблеми у вимірі соціології управління: матеріали XII Міжнародної науковопрактичної конференції, м. Маріуполь, 10 червня 2016 р. - Маріуполь: ДонДУУ, 2016. C 42-45. 